\title{
Prophylactic Effect of Potentilla fulgens on Renal Ischemia-Reperfusion Injury in Rats
}

\author{
Efecto Profiláctico de Potentilla fulgens sobre la Lesión \\ por Reperfusión por Isquemia Renal en Rata
}

Yaris, Mehmet ${ }^{1}$ \& Deveci, Engin ${ }^{2}$

YARIS, M. \& DEVECI, E. Prophylactic effect of Potentilla fulgens on renal ischemia-reperfusion injury in rats. Int. J. Morphol., 39(1):116-122, 2021.

SUMMARY: We aimed to investigate the possible protective effects of Potentilla fulgens on kidney tissue with ischemiareperfusion using immunohistochemical methods. Wistar rats were grouped as sham, ischemia, ischemia-reperfusion (I/R) and I/R treated with Potentilla fulgens. Renal vessels of the left rat kidney were clamped for 60 minutes for ischemia, IR group had $6 \mathrm{~h}$ of reperfusion. $400 \mathrm{mg} / \mathrm{kg}$ Potentilla fulgens were given intraperitoneally 5 days before ischemia+reperfusion procedure. Biochemical analysis (MDA, GSH and MPO) of samples were performed. Kidney tissues were fixed with $10 \%$ neutral formalin and routine paraffin tissue follow-up protocol was applied, stained with routine Hematoxylin and Eosin. ADAMTS-5 and Caspase-3 immunostaining was applied for immunohistochemistry and examined under a light microscope. In the ischemia group, inflammation and congestion in the vessels and increased ADAMTS-5 expression in glomerular cells and tubule cells were observed. In reperfusion, an increase in degenerative glomerular cells, tubule cells and intertubular connective tissue and inflammatory cells ADAMTS-5 expression was observed. In the P. fulgens group, degeneration and inflammation decreased and positive ADAMTS-5 expression was observed. In the ischemia and ischemia reperfusion group, increased apoptotic appearance and Caspase-3 positive expression in glomerular and tubular cells, and negative expression in most cells in the P. fulgens group. Potentilla fulgens are thought to stop apoptotic cell development at a certain stage, which affects the cytokine mechanism and plays an important role in the reduction of inflammatory cells and angiogenic regulation.

KEY WORDS: Potentilla fulgens; Renal ischemia, rat; ADAMTS-5; Caspase-3.

\section{INTRODUCTION}

Ischemia- reperfusion injury is an important model for testing therapeutic interventions in pathophysiological events leading to acute renal failure (Wang et al., 2012). Damage due to nutritional and oxygen restriction (ischemia) and recovery (reperfusion) is the main cause of acute kidney injury in developed countries with open heart surgery, and sepsis are important triggers (Bellomo et al., 2012). In the mechanism of occurrence of kidney, I/R damage, inflammatory mediators, adhesion molecules and various cytokines have been reported to cause chronic kidney damage if they do not recover within a short time (Fan et al., 2012).

Potentilla fulgens is an alpine plant of Western Himalayas which is consumed in all parts of the world for its promising medicinal properties. Pharmacologically, the aerial and root portions of the plant are reported to have antioxidant (in vitro models), antitumor, hypoglycemic and antihyperglycemic activities (Syiem et al., 2009; Kaul et al., 2011). The general signs and symptoms of toxicity, food and water intake and mortality rates of animals were observed within $72 \mathrm{~h}$ post-treatment. From these observations, LD50 was calculated using SPSS software (Chen et al., 2005). In general, the expression of Adamts5 at many of these locations or in cell types appears to be a constitutive feature of their phenotype. Many of these sites are known to express versican, an aggregating proteoglycan that was recently identified as a substrate of ADAMTS5 (Longpré et al., 2009). Caspase-dependent apoptosis was previously believed to be the only form of programmed cell death; however, emerging evidence suggests that necrosis could also be regulated (Ashkenazi \& Salvesen, 2014). Apoptosis and necrosis, tissue damage caused by kidney I / $\mathrm{R}$ play a role in inducing inflammation (Heinzelmann et al.,

\footnotetext{
${ }^{1}$ Department of Urology, Genesis Hospital, Diyarbakır, Turkey.

${ }^{2}$ Department of Histology and Embryology, Medical School, Dicle University, Diyarbakır, Turkey.
} 
1999). This inflammatory response has been reported to affect the activation of the complement system, induction of cytokines, chemokines and subsequent neutrophils influx (Heinzelmann et al.; Daemen et al., 2002).

In this study, we aimed to investigate the protective effects of Potentilla fulgens against renal ischemia reperfusion (I/R) injury in rats by means of biochemical, histopathological, and immunohistochemical examination.

\section{MATERIAL AND METHOD}

All experimental protocols were approved by the Local Ethical Committee of Health Sciences, Dicle University, Diyarbakır, Turkey. The use of animals was performed within the framework of protocols in Guide for the Care and Use of Laboratory Animals (2011) released by the National Research Council. Male Wistar albino rats (n:28), 3 to 4 months old, weighing 180 to $240 \mathrm{~g}$, were used for the study and individually housed in clean cages under standard conditions (light/dark cycle of $12 \mathrm{~h} / 12 \mathrm{~h}$ with 50 $70 \%$ humidity, at $25^{\circ} \mathrm{C} \pm 3{ }^{\circ} \mathrm{C}$ ) and fed with standard pellet diet and water ad libitum. The animals were randomly divided into four groups each consisted of seven animals; Group 1: Sham ( $\mathrm{n}=7)$, Group 2: ischemia $(\mathrm{n}=7)$, Group 3: ischemia and reperfusion ( $n=7)$, Group 4: Potentilla fulgens treated ischemia reperfusion $(n=7)$. Renal vessels of the left rat kidney were clamped for 60 minutes for ischemia, and I/ $\mathrm{R}$ group had $6 \mathrm{~h}$ of reperfusion. There was no loss of subjects until the end of the experiment.

Surgical procedure. After shaving the front of the abdomen, the median line opened with an incision. Blood flow was stopped from both kidney vessels through an atraumatic vascular clamp. After 60 minutes of ischemia, clamps were removed and blood flow was provided. Reperfusion procedure was applied for 6 hours. $400 \mathrm{mg} / \mathrm{kg}$ Potentilla fulgens were intraperitoneally given 5 days before ischemia + reperfusion procedure.

Histopathology and immunohistochemistry process. Kidney tissues were fixed with $10 \%$ neutral formalin and routine paraffin tissue follow-up protocol was applied. 4-6 $\mu \mathrm{m}$ sections were obtained from paraffin blocks with a microtome (Leica, Germany). Sections were kept in xylene for $2 \times 30$ minutes and brought to distilled water. Some of the sections were stained with routine Hematoxylin and Eosin, and the remaining were incubated for $3 \times 5$ minutes in PBS for immunostaining. Antigen release from the tissue was carried out twice (5 and $3 \mathrm{~min}$ ) in citrate buffer solution $(\mathrm{pH}: 6.0)$ in a microwave oven. The sections were allowed to cool for 20 minutes at room temperature and washed twice with distilled water for 4 minutes. Endogenous peroxidase blockage was performed in a $10 \%$ hydrogen peroxide solution for 7 minutes. The washed samples were incubated in Ultra V block (catalog no. TA-015UB, Thermo Fisher, US) for 8 minutes. Blocking solution was removed from the sections and allowed to incubate overnight at $+4{ }^{\circ} \mathrm{C}$ with primary antibodies ADAMTS-5 (catalog no: ab41037, Abcam, US) and Caspase-3 (catalog no: ab208161, Abcam, US). After washing the sections in PBS, a secondary antibody (TP-015-BN, Thermo Fisher) was applied for $20 \mathrm{~min}$. The sections were washed in PBS for $2 \times 5$ min and then exposed to streptavidin-peroxidase (TS-015-HR, Thermo Fisher, US) for $20 \mathrm{~min}$. Sections washed with PBS were allowed to react with DAB (TA-001-HCX, Thermo Fisher, US) chromogen. Counterstaining with hematoxylin was applied and after washing, the preparations were closed. Sections were examined under a light microscope (Zeiss Imager A2, Germany).

Statistical Analysis. The statistical analyses and bar graphs were prepared using SPSS 20.0 (IBM, US). The data are represented as the mean \pm SD and all data were statistically evaluated using one-way analysis of variance (ANOVA) with Tukey post-hoc tests. The confidence interval was set at 95 $\%$, and $\mathrm{P}$ values $<0.05$ and $<0.01$ were considered as significant. Histopathologic assay of preparations for tubular degeneration, vascular dilatation and congestion and inflammation were performed in a blind manner by the histopathologist. Ten (10) fields were counted for each criterion and semi-quantitative histological evaluation scoring system (from 0 to 4 ) was used to determine histopathological changes.

\section{RESULTS}

The level of MDA in the IR group rats was significantly higher than the control group $(p<.001)$. The level of MDA has decreased significantly after treatment with Potentilla fulgens compared to the IR group. ( $\mathrm{p}<.001$ ). The level of GSH in the IR group rats decreased significantly ( $\mathrm{p}<.001)$ compared to the control group, and the MPO level was found higher than the control group. After treatment with Potentilla fulgens, GSH and MPO values were significantly close to control (Table I). The total score of kidney histomorphological damage was significantly lower in the control group compared to ischemia and ischemia reperfusion group ( $\mathrm{p}<0.01)$. Histomorphological damage total scores in the ischemiareperfusion + Potentilla fulgens $(\mathrm{PF})$ group were slightly above the control group (Table I). 
Table I. Statistical analysis of MDA, GSH, MPO, degeneration in tubular cells, vascular dilatation and congestion, inflammation values of the groups.

\begin{tabular}{|c|c|c|c|c|c|c|}
\hline & MDA & GSH & MPO & $\begin{array}{l}\text { Degeneration in } \\
\text { tubular cells }\end{array}$ & $\begin{array}{l}\text { Vascular dilatation } \\
\text { and congestion }\end{array}$ & Inflammation \\
\hline Control & $33.54 \pm 2.83$ & $1.19 \pm 0.12$ & $3.81 \pm 0.49$ & $0.44 \pm 0.53$ & $0.44 \pm 0.53$ & $0.38 \pm 0.52$ \\
\hline Is chemia & $51.96 \pm 1.96^{*}$ & $0.70 \pm 0.10^{*}$ & $7.85 \pm 0.83 *$ & $3.67 \pm 0.50 *$ & $3.56 \pm 0.53 *$ & $3.67 \pm 0.50 *$ \\
\hline $\mathrm{I} / \mathrm{R}$ & $51.71 \pm 2.31^{*}$ & $0.72 \pm 0.12 *$ & $8.14 \pm 0.70 *$ & $3.78 \pm 0.44 *$ & $3.56 \pm 0.53 *$ & $3.78 \pm 0.44 *$ \\
\hline $\mathrm{I} / \mathrm{R}+\mathrm{PF}$ & $35.52 \pm 3.48$ & $1.15 \pm 0.10$ & $3.78 \pm 0.41$ & $1.11 \pm 0.60$ & $0.78 \pm 0.44$ & $0.89 \pm 0.60$ \\
\hline
\end{tabular}

Values with different superscript show statistical significance between groups, $\mathrm{p} *<0.01$.

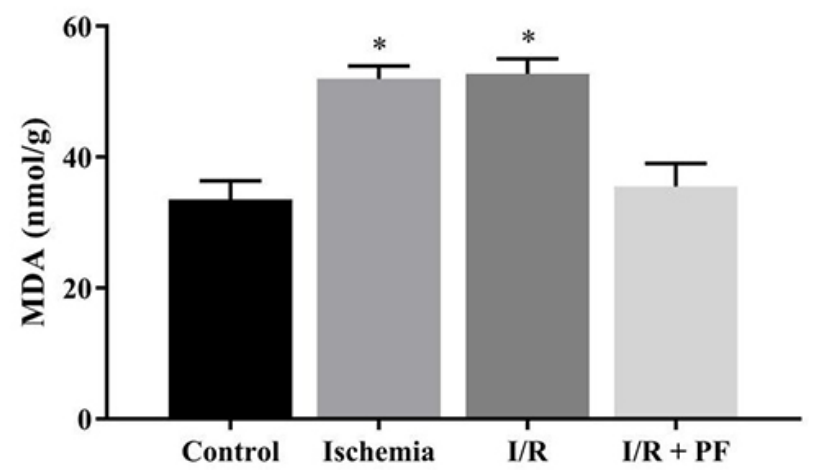

Fig. 1. MDA analysis results of the groups, $\mathrm{p} *<0.01$.

\section{DISCUSSION}

Ischemia is an important blockage occurring in the circulatory system and the damage it will cause depends on ischemic time. The reperfusion mechanism takes place as a return and determines the result of the damage (Daemen $e t$ al.). The severity of ischemia / reperfusion (IR) injury depends on the ischemic duration and the adequacy of the collateral circulation. In the pathophysiology of renal ischemia reperfusion, inflammation and tubular epithelial cell apoptosis occur, causing excessive production of
Reactive oxygen species (ROS), cell apoptosis and release of inflammatory cytokines, causing tissue damage (Li et al., 2014). MDA as a marker of lipid peroxidation shows the degree of peroxidation after renal ischemia injury. GSH, GSH-Px, CAT and SOD are the most important endogenous antioxidant enzymes and are found in high concentrations in kidney cells. GSH removes superoxide radicals and protects protein thiol (-SH) groups from oxidation. MPO and oxidation products are considered critical pathogenic factors in many kidney diseases and contribute to the development of different kidney damage (Day et al., 2005). GSH is an endogenous tripeptide and is found in kidney cells, especially at high concentrations. GSH removes superoxide radicals and protects protein thiol groups from oxidation (Ross, 1988). In our study, MDA values in ischemia and ischemia-reperfusion groups were high and decreased after Potentilla fulgens treatment (Fig. 1). It was observed that $\mathrm{P}$. Fulgens decreased the lipid peroxidation. In addition, the level of GSH in IR group rats decreased significantly ( $p$ $<.001$ ) compared to the control group, and MPO level was found higher than the control group. After treatment with Potentilla fulgens, significant GSH and MPO values were close to control (Fig. 2). After ischemic damage in the kidneys, tubular necrosis,fibrosis and inflammatory cells have been proliferated and accumulated in the damage area. It has been reported that apoptotic cell death directly or

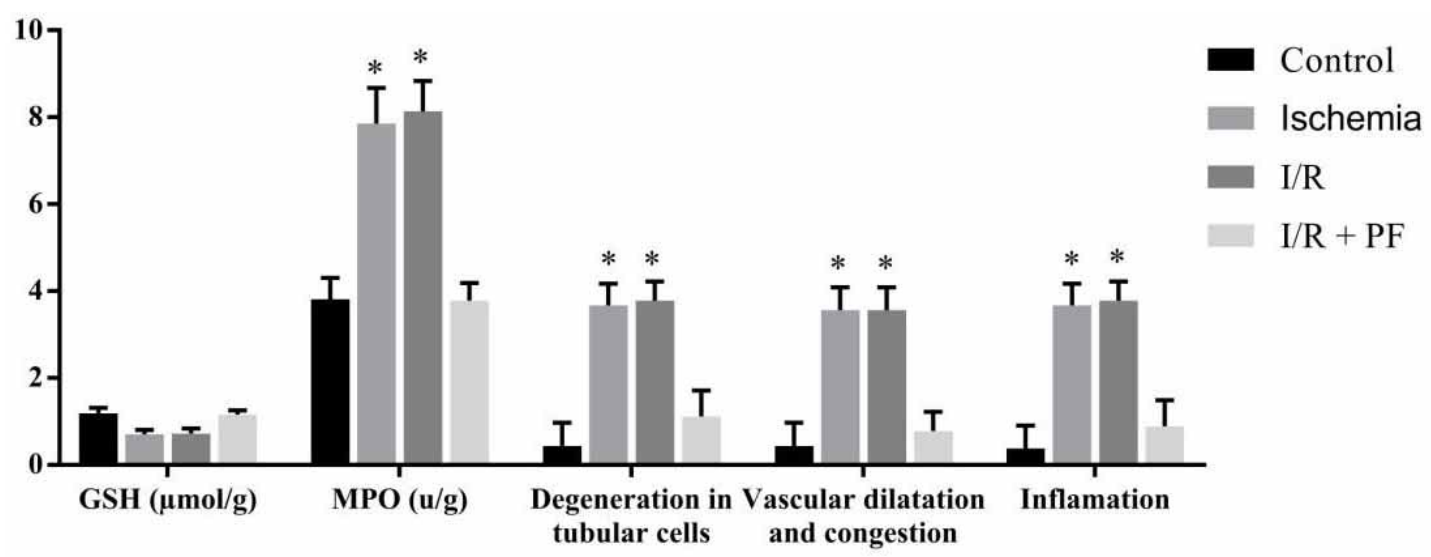

Fig. 2. GSH, MPO, degeneration in tubular cells, vascular dilatation and congestion, inflammation results of groups, $\mathrm{p}<0.01$. 

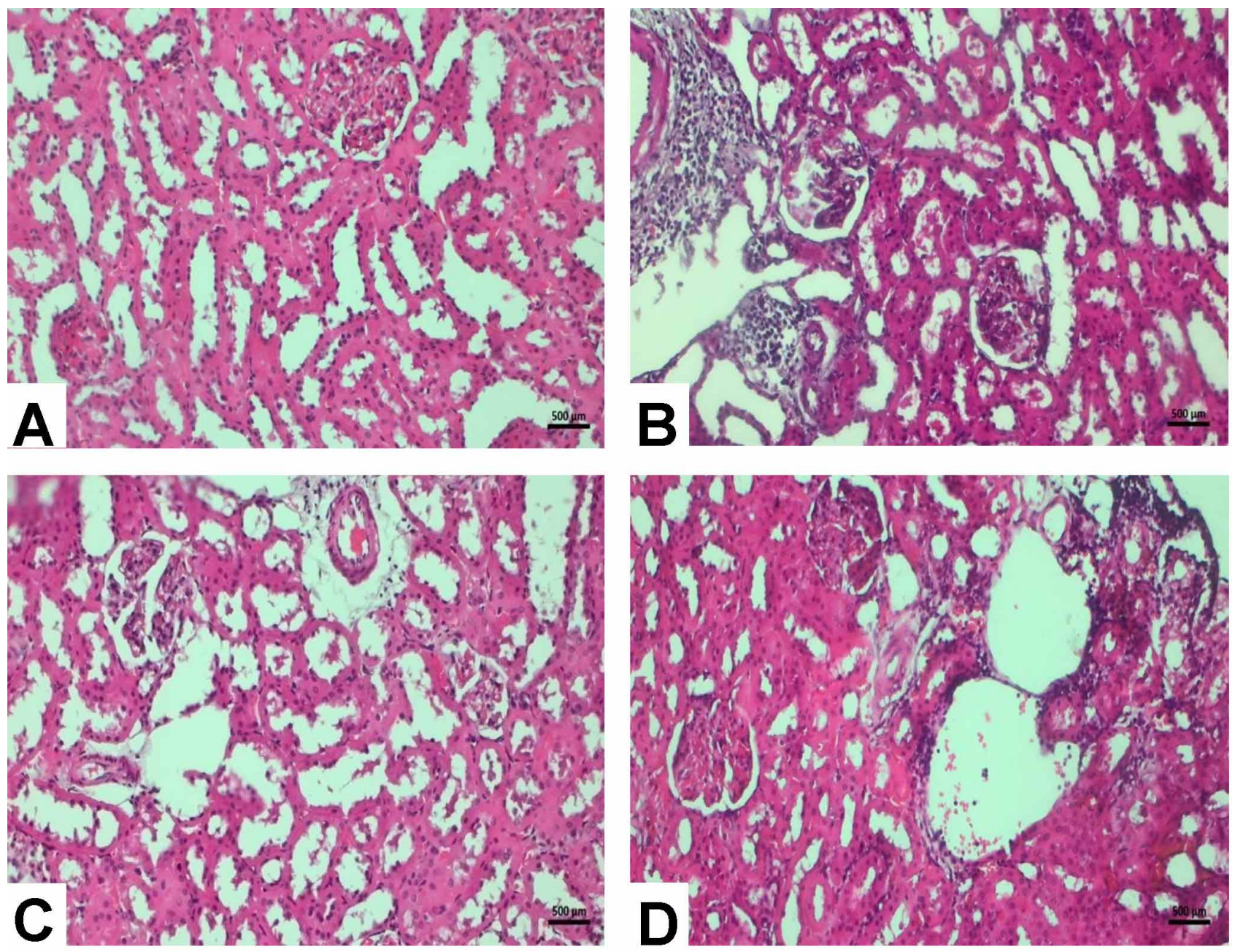

Fig. 3. Hematoxylin-Eosin staining of kidney tissue of all groups. a) No changes were observed in the glomerular structures in the cortex region of the control group kidney sections and in the formations in the juxtaglomerular apparatus area. Epithelium cell sizes in proximal and distal tubules were observed in normal view. b) In the ischemia group, degenerative changes in cells in the glomerular area, deterioration in bowman capsule structure, inflammatory cell infiltration in the juxtaglomerular region, dilatation in the blood vessels were observed. In the proximal and distal tubule lumens, irregularity, pyknosis and apoptotic appearance were observed in the cell nuclei. c) In the ischemia-reperfusion group, there was an increase in inflammation cells in a wide area around the glomerular structures along with necrosis, glomeruli and tubules. Nucleus loss was observed in the nuclei of tubular cells with apoptosis. d) In the ischemia-reperfusion + Potentilla fulgens group, there was a decrease in degenerative appearance in the cells in the glomerular structure, and lumens of tubular structures, while apoptotic changes were observed in some of the regular cells.

indirectly contributes to I / R-induced inflammation and the resulting tissue damage (Day et al., 2006; Delbridge, 2007). In our study, an increased inflammatory cell infiltration around the glomerulus and tubule in the ischemia group (Fig. $3 b$ ), advanced necrotic structures and apoptotic cells in the reperfusion group were observed (Fig. 3c). In the group treated with P. Fulgens, it was observed that the inflammation decreased and the necrotic structures were low and apoptotic cells decreased (Fig. 3d).
ADAMTS-5 is also known as aggrecan-2, a major component of extracellular matrix and ADAMTS-5 gene known to be expressed in bladder, cervix, esophagus, placenta and uterus (Porter et al., 2005). The role of ADAMTS-5 in renal injury has not yet been studied.

In our study, we observed that ADAMTS-5 expression increased in kidney damage that developed with ischemia (Fig. 4b) and after ischemia reperfusion (Fig. 4c), 

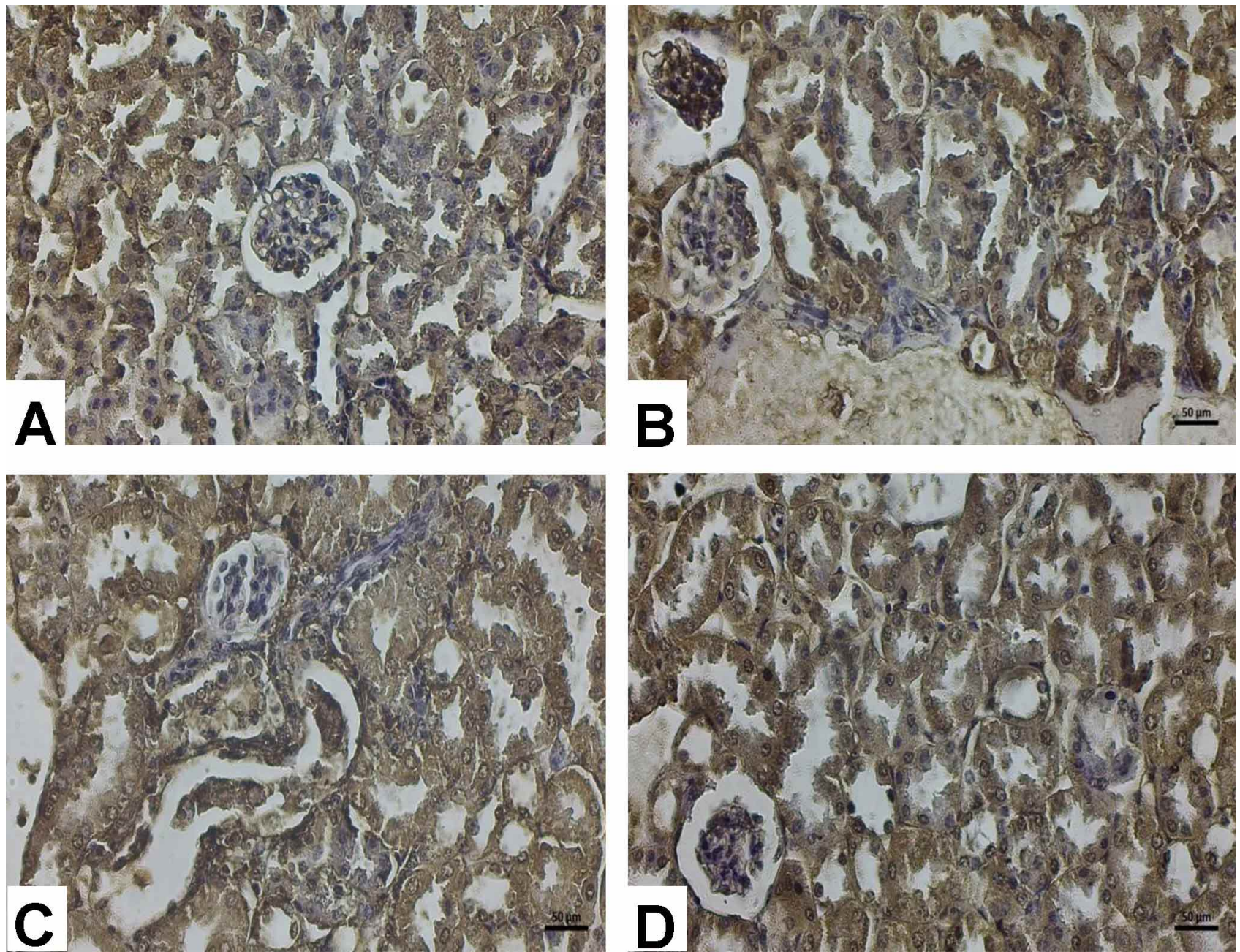

Fig. 4. ADAMTS5 immunostaining. a) In the control group sections, ADAMTS-5 expression was observed mildly in most glomerular cells. Expression of ADAMTS-5 was positive in cells and fibroblast cells in tubular and intertubular connective tissue areas. b) In the ischemia group, ADAMTS-5 expression was positive in glomerular cells and tubule cells, and an increase in ADAMTS-5 expression in inflammatory cells in connective tissue cells in the inter-tubular area. c) In the ischemia-reperfusion group, an increase in ADAMTS-5 expression was observed in degenerative glomerular cells, tubule cells, and intertubular connective tissue and inflammatory cells. d) In the ischemia-reperfusion + potentilla fulgens group, mild ADAMTS-5 expression was observed in some of the glomerular cells and most of the tubule cells, while ADAMTS-5 expression was positive in some inflammatory cells that formed a small aggregate between the tubules and some connective tissue cells and fibers.

increased inflammatory cell, and increased extracellular matrix. We found moderate ADAMTS-5 expression in some extracellular areas with a decrease in inflammatory cells in Potentilla fulgens application (Fig. 4d). ADAMTS-5 can play important pathogenic roles in the progression of kidney damage. Baloglu et al. (2018) has stated that treatment of P. fulgens in spinal cord injury may decrease the apoptotic cell count of nerve and glial cells, causing cytokine mechanism to decrease, inflammatory cells and angiogenic progression. There are no studies on P. fulgens treatment on kidney ischemia reperfusion. Tunç et al. (2015) have demonstrated that Potentilla fulgens treatment on intestinal ischemia reperfusion injury can inhibit cellular apoptosis of mucosal cells and trigger cell proliferation and reduce intestinal permeability to accelerate regeneration and repair of the small intestinal mucosa. In the study of Acar et al. (2016), P. fulgens treatment in ovarian torsion prevented degeneration in tuba uterina epithelium, blocking of blood vessels and inflammatory cell infiltration. They suggested using Potentilla fulgens as an antioxidant. Caspases are a family of genes maintaining homeostasis through regulating cell death and inflammation. They participate in ordered processes such as apoptosis and inflammation. Caspases are classified according to their roles in apoptosis; caspase-3 

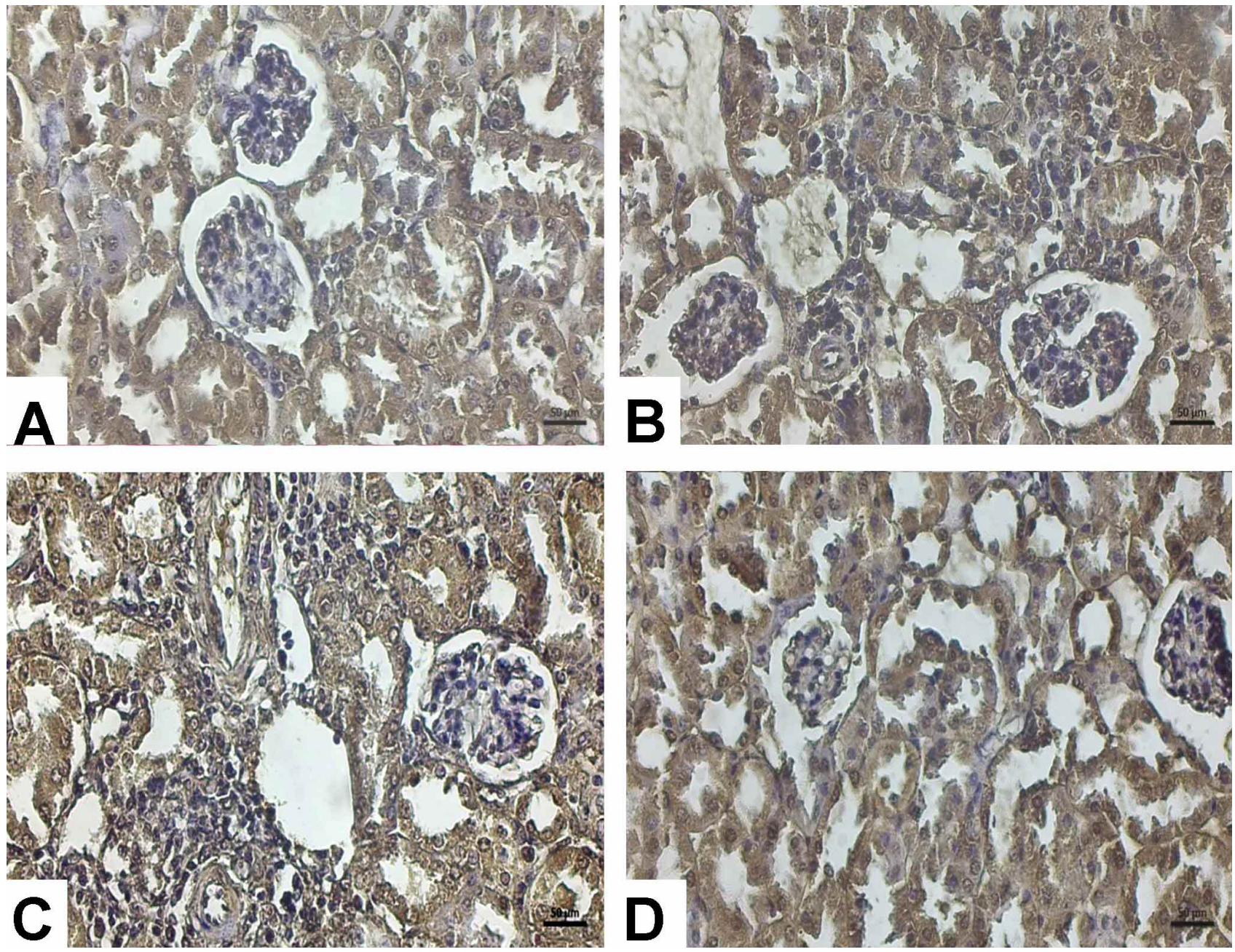

Fig. 5. Caspase-3 immunostaining. a) In the control group, negative capacity-3 expression was observed in cells in the glomerular structure while caspase- 3 expression was observed in mild tubular cells. b) In the ischemia group, caspas- 3 expression was positive in blood vessel endothelial cells, tubular cells and intertubular connective tissue cells in visceral cells in the glomerular area. c) In the ischemia-reperfusion group, in the glomerular structure, most of the visceral and parietal cells, an increase in tubule cells and an increase in inflammatory cells, and caspase-3 expression were observed. d) While in the ischemia-reperfusion + potentilla fulgens group, glomerul cells and tubule cells were positive in some of the caspase- 3 , in the majority of them, the expression of caspase- 3 was negative.

acts as an executioner caspase (McIlwain et al., 2013). In the ischemia (Fig. 5b) and ischemia-reperfusion group (Fig. $5 \mathrm{c})$, most of the visceral and parietal cells in glomerular structure, caspas-3 expression was observed with an increase in apoptosis in tubule cells. In the Potentilla fulgens-treated group, the expression of caspase- 3 was positive in some of the glomerular cells and tubule cells, whereas caspase- 3 expression was negative in most (Fig. 5d).

Potentilla fulgens are thought to stop apoptotic cell development at a certain stage, which affects the cytokine mechanism and plays an important role in the reduction of inflammatory cells and angiogenic regulation.
YARIS, M. \& DEVECI, E. Efecto profiláctico de Potentilla fulgens sobre la lesión por reperfusión por isquemia renal en ratas. Int. J. Morphol., 39(1):116-122, 2021.

RESUMEN: El objetivo de este estudio fue investigar los posibles efectos protectores de Potentilla fulgens en el tejido renal con isquemia-reperfusión utilizando métodos inmunohistoquímicos. Se agruparon ratas Wistar como simulación, isquemia, isquemia-reperfusión (I / R) e I / R tratadas con Potentilla fulgens. Los vasos renales del riñón izquierdo de las ratas se fijaron durante $60 \mathrm{~min}$ por isquemia, el grupo de IR tuvo $6 \mathrm{~h}$ de reperfusión. Se administraron $400 \mathrm{mg} / \mathrm{kg}$ de Potentilla fulgens por vía intraperitoneal 5 
días antes del procedimiento de isquemia + reperfusión. Se realizaron análisis bioquímicos (MDA, GSH y MPO) de muestras. Los tejidos renales se fijaron con formalina neutra al $10 \%$ y se aplicó el protocolo de seguimiento de tejido de parafina de rutina y teñido con hematoxilina y eosina. Se aplicó inmunotinción de ADAMTS-5 y Caspasa-3 para inmunohistoquímica y se examinó con un microscopio óptico. En el grupo de isquemia, se observó inflamación y congestión en los vasos y el aumento de la expresión de ADAMTS-5 en células glomerulares y células tubulares. En la reperfusión, se observó un aumento en la expresión de ADAMTS-5 de células glomerulares degenerativas, células tubulares y tejido conjuntivo intertubular y células inflamatorias. En el grupo de Potentilla fulgens, la degeneración y la inflamación disminuyeron y se observó expresión positiva de ADAMTS-5. En el grupo de isquemia y reperfusión de isquemia, aumentó la apariencia apoptótica y expresión positiva de Caspasa-3 en células glomerulares y tubulares, y expresión negativa en la mayoría de las células del grupo de Potentilla fulgens. Se cree que Potentilla fulgens detiene el desarrollo de las células apoptóticas en una determinada etapa, lo que afecta el mecanismo de las citocinas y juega un papel importante en la reducción de las células inflamatorias y la regulación angiogénica.

PALABRAS CLAVE: Potentilla fulgens; Isquemia renal; Rata; ADAMTS-5; Caspasa-3

\section{REFERENCES}

Acar, Z.; Deger, U.; Görkem, Ü.; Togrul, C.; Deveci, E.; Kaya, S. \& Ekinci, A. Effects of Potentilla fulgens on tuba uterina in ovariectomized rats. Int. J. Morphol., 34(2):460-4, 2016

Ashkenazi, A. \& Salvesen, G. Regulated cell death: signaling and mechanisms. Annu. Rev. Cell Dev. Biol., 30:337-56, 2014.

Baloglu, M.; Çetin, A. \& Tuncer, M. C. Neuroprotective effects of Potentilla fulgens on spinal cord injury in rats: an immunohistochemical analysis. Folia Morphol. (Warsz.), 2018. DOI: https://www.doi.org/10.5603/ FM.a2018.0050

Bellomo, R.; Kellum, J. A. \& Ronco, C. Acute kidney injury. Lancet, 380(9843):756-66, 2012.

Chen, W.; Fu, X. B.; Ge, S. L.; Sun, T. Z.; Li, W. J. \& Sheng, Z. Y. Acid fibroblast growth factor reduces rat intestinal mucosal damage caused by ischemia-reperfusion insult. World J. Gastroenterol., 11(41):6477$82,2005$.

Daemen, M. A. R. C.; de Vries, B. \& Buurman, W. A. Apoptosis and inflammation in renal reperfusion injury. Transplantation, 73(11):1693700,2002

Day, Y. J.; Huang, L.; Ye, H.; Li, L.; Linden, J. \& Okusa, M. D. Renal ischemia-reperfusion injury and adenosine $2 \mathrm{~A}$ receptor-mediated tissue protection: the role of CD4+ T cells and IFN-gamma. J. Immunol., 176(5):3108-14, 2006.

Day, Y. J.; Huang, L.; Ye, H.; Linden, J. \& Okusa, M. D. Renal ischemiareperfusion injury and adenosine $2 \mathrm{~A}$ receptor-mediated tissue protection: role of macrophages. Am. J. Physiol. Renal Physiol., 288(4):F722-31, 2005.

Delbridge, M. S.; Shrestha, B. M.; Raftery, A. T.; El Nahas, A. M. \& Haylor, J. L. Reduction of ischemia-reperfusion injury in the rat kidney by FTY720, a synthetic derivative of sphingosine. Transplantation, 84(2):187-95, 2007.

Fan, L. H.; He, L.; Cao, Z. Q.; Xiang, J. \& Liu, L. Effect of ischemia preconditioning on renal ischemia/reperfusion injury in rats. Int. Braz. J. Urol., 38(6):842-54, 2012.
Heinzelmann, M.; Mercer-Jones, M. A. \& Passmore, J. C. Neutrophils and renal failure. Am. J. Kidney Dis., 34(2):384-99, 1999.

Kaul, K.; Jaitak, V. \& Kaul, V. K. Review on pharmaceutical properties and conservation measures of Potentilla fulgens Wall. ex Hook. - A medicinal endangered herb of higher Himalaya. Indian J. Nat. Prod. Resour., 2(3):298-306, 2011.

Li, Y. W.; Zhang, Y.; Zhang, L.; Li, X.; Yu, J. B.; Zhang, H. T.; Tan, B. B.; Jiang, L. H.; Wang, Y. X.; Liang, Y.; et al. Protective effect of tea polyphenols on renal ischemia/reperfusion injury via suppressing the activation of TLR4/NF-kB p65 signal pathway. Gene, 542(1):46-51, 2014.

Longpré, J. M.; McCulloch, D. R.; Koo, B. H.; Alexander, J. P.; Apte, S. S. \& Leduc, R. Characterization of proADAMTS5 processing by proprotein convertases. Int. J. Biochem. Cell Biol., 41(5):1116-26, 2009.

McIlwain, D. R.; Berger, T. \& Mak, T. W. Caspase functions in cell death and disease. Cold Spring Harb. Perspect. Biol., 5(4):a008656, 2013.

Porter, S.; Clark, I. M.; Kevorkian, L. \& Edwards, D. R. The ADAMTS metalloproteinases. Biochem. J., 386(Pt. 1):15-27, 2005.

Ross, D. Glutathione, free radicals and chemotherapeutic agents. Mechanisms of free-radical induced toxicity and glutathione-dependent protection. Pharmacol. Ther, 37(2):231-49, 1988.

Syiem, D.; Khup, P. Z. \& Syiem, A. B. Effects of Potentilla fulgens Linn. on carbohydrate and lipid profiles in diabetic mice. Pharmacologyonline, 2:787-95, 2009.

Tunç, N.; Tas, M.; Görük, M.; Kirman, G. \& Deveci, E. Effects of Potentilla fulgens as prophylactic agent in intestinal ischemia reperfusion injury. Int. J. Morphol., 33(4):1313-8, 2015.

Wang, H. J.; Varner, A.; AbouShwareb, T.; Atala, A. \& Yoo, J. J. Ischemia/ reperfusion-induced renal failure in rats as a model for evaluating cell therapies. Ren. Fail., 34(10):1324-32, 2012.

Corresponding author:

Engin Deveci

Department of Histology and Embryology

Faculty of Medicine

University of Dicle, 21280

Diyarbakır

TURKEY

Email: devecie@mynet.com

Received: 15-07-2020

Accepted: 08-09-2020 